\title{
Collaborative Strategic Reading (CSR) to Improve Students' Achievement in Reading Comprehension
}

\author{
Doni Sudibyo \\ Universitas Pendidikan Muhammadiyah Sorong \\ donisud06@gmail.com \\ Areski Wahid \\ Universitas Pendidikan Muhammadiyah Sorong \\ areskiwahidddd@gmail.com \\ Ismail Suardi Wekke \\ Institut Agama Islam Negeri (IAIN) Sorong
}

\begin{abstract}
Reading is the most important activity in any language class, not only as a source of information and a pleasurable activity, but also as a means of consolidating and extending one's knowledge of the language. In this case, the teaching of reading is essential for preparing students with the basic reading skill in order to be able to gain information and knowledge from any reading text. In the process of learning, the central goal of reading is to develop learners' comprehension. In this case, the researcher proposes Collaborative Strategic Reading (CSR) as a technique of teaching reading in general English classes. The researcher formulates the statement of the problems in the form of questions as: (1) is there any significant improvement of students' achievement in reading comprehension after being taught by using Collaborative Strategic Reading (CSR)? (2) How do the students respond to Collaborative Strategic Reading (CSR) in the teaching of reading comprehension?. Since the present study is to measure the effect of Collaborative Strategic Reading (CSR) towards the students' reading comprehension achievement, it is classified into quantitative research. Here, the researcher collected numerical data by comparing the results of pre-test and post-test between two groups of experimental study - control and experimental groups. The data is used to investigate whether there is a significant increase in students' reading comprehension achievement after being given the Collaborative Strategic Reading (CSR) treatment in reading class. After the data of this research was found to be distributed normally, through the calculation of the normality test, there was also a need to identify the homogeneity of the data of the whole scores of the test for both experimental and control groups. The results of the calculation of the $t$-test indicate that the score of the $t_{\text {value }}$ is bigger than $t_{\text {table }}(2.18>2.021)$. This means that there is a significant improvement in the students' achievement after they were treated using Collaborative Strategic Reading (CSR) strategy when studying reading comprehension in the classroom. The results of the analysis of the students' response to the application of Collaborative Strategic Reading (CSR) strategy in the teaching learning activities in the classroom provide a strong preference for the students study reading comprehension using Collaborative Strategic Reading (CSR) strategy. Since this current study is an action research, it is advisable that future researchers could follow up the results of this study for the development of similar research in the field of teaching methods and strategies. This is strongly suggested because there is still plenty of problems and the essences of Collaborative Strategic Reading (CSR) strategy that need to be uncovered. It is also important to see how Collaborative Strategic Reading (CSR) could be applied in the other language skills, not only for the students of the tertiary education but also at the secondary education.
\end{abstract}

Keywords: Reading achievement, reading comprehension, collaborative Strategic Reading (CSR).

\section{INTRODUCTION}


There are various purposes of teaching English which have been stated in English curriculum in the Indonesia. One of the main purposes is to develop students' skill in reading, speaking, writing, and listening. Developing reading skill so far has been the concern of many experts in Indonesia. This means that students' reading skill should be developed prior to the other skills. The importance of developing reading skill is strengthened by Rivers (1981:259) who explains that reading is the most important activity in any language class, not only as a source of information and a pleasurable activity, but also as a means of consolidating and extending one's knowledge of the language. In this case, the teaching of reading is essential for preparing students with the basic reading skill in order to be able to gain information and knowledge from any reading text.

Guthrie (1994) divides the characteristics of motivation into five types. They are: (a) curiosity, as in the desire to learn about a topic; (b) aesthetic involvement, as in the enjoyment of experiencing a literary text; (c) challenge, as in the orientation to learning complex ideas from text; (d) recognition, as in the fulfillment in receiving a tangible form of reward for success in reading; and (e) grades, as in favorable evaluations from a teacher.

As in the English Department at any university level in Indonesia, English in the English Education Program of Universitas Pendidikan Muhammadiyah Sorong is classified into General English or English for general purposes (EGP). In relation to EGP context, reading ability is vital for students to understand scientific texts written in English. Here, the teaching of EGP emphasizes on the development of reading skill with the focus being given to the adequate reading proficiency in which the students are expected to develop their knowledge concerning with a certain context given to them to learn. They are also expected to be able to extract meaning from specific clues in the text, get the gist of it, and obtain specific information from the reading text.

In teaching EGP reading, the English teachers are demanded to provide students with a good reading foundation in order to make them obtain adequate proficiency in scientific reading texts related to their interest in future. To achieve this aim, the EGP teachers need to devise learning and teaching activities that are suitable with students' need and interest.

Dealing with the problems above, the EGP teachers as the key factor in the learning process should motivate the students to attend actively in reading class. For this reason, the teachers may offer guidance in helping students to engage in the thinking process (Brown, 2001: 340). However, there have been a number of problems faced by the teacher in the teaching of reading. One of them deals with learning strategy. An appropriate strategy, which provides interesting activities, will encourage students to be active and realize the demand they are supposed to have. Considering the above conditions, it is necessary to provide a model of teaching strategy that may help students create a good learning atmosphere to take part actively in the classroom activity in order to increase their achievement in reading comprehension. In this case, the researcher proposes Collaborative Strategic Reading (CSR) as a technique of teaching reading in general English classes. This technique is particularly interesting from foreign language standpoint because it is effective with students, including language minority students. Moreover, it is assumed that the technique is the best method to solve the common problems of English classroom on reading comprehension and give benefits to the learning process such as in motivating the 
students, improving social interaction in the classroom, creating a positive learning environment, and improving reading skill.

Collaborative Strategic Reading (CSR) is an excellent teaching technique for teaching students reading comprehension and building vocabulary and also working together cooperatively (Klingner, 2002). This technique is a way to help foreign language learners engage with difficult text and use the key reading strategies to improve comprehension. Grabe (2009: 233) claims that CSR is a promising approach to combined-strategies instruction that draws on both reciprocal teaching and cooperative learning, and that has been used with both L1 and L2 students. Various lines of research on this approach indicate that CSR is an effective teaching tool that has the potential to enhance reading comprehension of (a) students with learning disabilities, (b) low- and average achieving students, and (c) English language learners (Bryant, Vaughn, Linan-Thompson, Ugel, Hamff, and Hougen, 2000; Klingner and Vaughn, 2012; Klingner, Vaughn, and Schumm, 2002).

Here, students work in groups and they are taught to activate their prior knowledge, to make prediction, to monitor their comprehension difficulties, to clarify information, to restate important ideas based on the text, to summarize the text, and to form appropriate questions about the text. The group work is organized around cooperative learning principles with each student in a group assigned a responsibility for the task. Such activities of running Collaborative Strategic Reading (CSR) in the classroom was be observed in English for General Purposes (EGP) classes in the English Education Program of Universitas Pendidikan Muhammadiyah Sorong. The implementation of this research was be realized following the research questions and the purposes of studying this topic that be briefly described in the following sections.

\section{LITERATURE REVIEW}

\section{Previous Related Studies}

Reading in general is often defined as the process of receiving and interpreting information encoded in language form via the medium of print or written verbal symbol (Urquhart and Weir, 1998 in Grabe, 2009: 14

Reading comprehension requires a reader to read for thorough comprehension, a skill that students should achieve if they want to be successful readers. McNeil (1992: 10) states that reading comprehension means searching for meaning actively by using the knowledge of the world and of text to understand each new thing. There are three elements that encompass this definition: (a) a reader needs knowledge of the world to understand new things; (b) a reader needs to be familiar with the variety of text structure she or he is likely to encounter; and (c) a reader needs to seek meaning and not passively for it to rise up from the page.

CSR is an excellent teaching technique for teaching students reading comprehension and building vocabulary and also working together cooperatively (Klingner, 1998). This technique is a way to help second language learners engage with difficult text and use the key reading strategies to improve comprehension.

In addition, according to Grabe (2009: 233), CSR is a promising approach to combined-strategies instruction that draws on both reciprocal teaching and cooperative learning, and this approach has been used with both L1 and L2 students. Here, students are working in groups and taught to activate prior knowledge, make predictions, 
monitor their comprehension difficulties, clarify information, restate important ideas, summarize the text, and form appropriate questions about the text.

To use this approach, first, the teacher presents the strategies to the whole class using modeling, role playing, and teacher think-aloud (students are prompted to voice their thoughts before, during, and after reading). After students have developed proficiency to use the strategies, the teacher then assigns the students to heterogeneous cooperative learning groups (Johnson and Johnson, 1989; Kagan, 1991, in Klingner, 2007: 139). All the students are actively involved, and everyone has the opportunity to contribute as group members learn from and understand the text with Collaborative Strategic Reading (CSR).

In more specific way, Spielberger (2002: 17) explains that Collaborative Strategic Reading (CSR) combines instruction in comprehension strategies and study skills with collaborative peer practice. Students learn four strategies through direct instruction and teacher modeling: (a) preview (i.e., preview and predicting), (b) click and clunk (i.e., monitoring for understanding and vocabulary knowledge), (c) get the gist (i.e., understanding the main idea, and (d) wrap-up (i.e., self questioning for understanding). It is believed that CSR has been successful in improving reading proficiency in regular education, multilevel, inclusive, and special education settings. Originally, Collaborative Strategic Reading (CSR) designed for use with expository text in content area textbooks, but it can also be applied to narrative material.

The goals of Collaborative Strategic Reading (CSR) are to improve reading comprehension and increase conceptual learning in ways that later maximize students' participation. Formerly, Collaborative Strategic Reading (CSR) developed to help English language learners and students with learning disabilities in order to make them become more confident and competent readers in heterogeneous classrooms. Furthermore, Collaborative Strategic Reading (CSR) has also proven to be a valuable approach for students at varying achievement levels because it provides students with a more independent way to learn.

Based on the above definitions, it can be stated that reading comprehension is a process that involves active constructing of meaning among the parts of the text, and between the text and personal experience. It is the ability to understand the new information in light of what the reader already knows.

\section{METHODOLOGY}

Since the present study is to measure the effect of Collaborative Strategic Reading (CSR) towards the students' reading comprehension achievement, it is classified into quantitative research. Here, the researcher was collected numerical data by comparing the results of pre-test and post-test between two groups of experimental study - control and experimental groups. The data is used to investigate whether there is a significant increase in students' reading comprehension achievement after being given the Collaborative Strategic Reading (CSR) treatment in reading class.

Muijs (2004: 18) describes that the experimental design is also known as the pre-test post-test control group design, which works chronologically in the way that participants (often known as 'subjects' in experimental research) are placed into two groups, the experimental and the control group. Moreover, the experimental group received treatment, meanwhile the control group not. Both groups was received a pre- 
test before the treatment is given, and a post-test, usually with the same instrument, after the treatment has been given.

The research used in the experimental design as the following:

$$
\begin{aligned}
& G_{1}=T_{1} \quad X \quad T_{2} \\
& G_{2}=T_{1} \quad 0 \quad T_{2}
\end{aligned}
$$

where:

$G_{1}:$ experimental group

$G_{2}$ : control group

$T_{1}$ : pre-test

$T_{2}:$ post-test

$X \quad$ : treatment (Collaborative Strategic Reading (CSR))

0 : no treatment

The research design has the following features:

1. It is conducted in a classroom setting in which the classes has been set up into classes, such as A, B, and C. Two out of three classes are randomly assigned; one group is used as the experimental group, and the other one is used as the control group.

2. Two groups are compared with respects to measurement on the dependent variable that is students' reading achievement.

3. The pre-test and post-test administered to both of groups at the same time with the same test.

4. In experimental group, Collaborative Strategic Reading (CSR) is carried out in teaching reading comprehension; meanwhile, in control group, the class is taught by conventional teaching reading activities.

\section{FINDING AND DISCUSSION}

The try-out of the instrument was conducted at the English Education Program of Universitas Pendidikan Muhammadiyah Sorong, and attended by 30 selected students. The results of the calculation of the reliability level of the try-out items using Spearmen Brown's Prophecy Formula show that the coefficient correlation of the whole items indicates 0.79 . It means that the reliability of the try-out items is moderate.

On the basis of the rules for determining the reliability and validity of the test items, it was found that all of the test items used in both pre-test and post-test sessions is reliable and valid. In other words, the result of the research, obtained from the use of this test items, could also be classified as reliable and valid. In addition to determining the reliability and validity of the try-out test items, the researcher also conducted the calculation of the level of difficulty of the test. Here, the results of the calculation of the difficulty index of the 40 items of the try-out test are presented in the following table.

Difficulty Index of the Try-out Test Items

\begin{tabular}{|l|l|}
\hline Number of Test Items & Levels of Difficulty \\
\hline $7,15,23,24,25,26,27,28,29,30$ & Difficult \\
\hline $\begin{array}{l}6,8,9,10,14,17,18,19,20,22,31, \\
32,33,34,35,36,37,38,39,40\end{array}$ & Moderate \\
\hline
\end{tabular}




\section{\begin{tabular}{|l|l|}
\hline $1,2,3,4,5,11,12,13,16,21$ & Easy
\end{tabular}}

The table indicates that 10 test items was found to be difficult, 20 test items was moderate, and 10 test items was easy. In this case, the criteria of the try-out test items comply with at least one of the criteria of good test suggested by Arifin (2009: 271) in which a good test should consists of $25 \%$ of difficult items, $50 \%$ of moderate items, and $25 \%$ of easy items.

The last consideration in deciding the eligibility of test items being used for both pretest and post-test was calculating the discriminating power of the try-out test items. The results of the calculation of the discriminating power of the revised instrument suggest that a certain test items are revised if the discrimination power is below 0.30 (DP < 0.30). Since none of the test items used in this research is below 0.30 (see appendix 6), so that the levels of difficulty of the try-out test items are categorized into very good and reasonably good. Consider the following table.

\section{Discrimination Power of the Try-out Test Items}

\begin{tabular}{|l|l|}
\hline Number of Test Items & Levels of Difficulty \\
\hline $1,2,3,4,5,6,8,9,10,11,13,15,18,19,21,23$, & Very good \\
$24,27,31,32,33,35,36,38,39,40$ & \\
\hline $7,12,14,16,17,20,22,25,26,28,29,30,34,37$ & Reasonably good \\
\hline
\end{tabular}

It can be inferred from the table that 26 test items of the 40 try-out test items are categorized very good and 14 test items belong to the category of reasonably good. It means that none of the try-out test items need revision, which may also be interpreted that all of the test items are eligible for both pre-test and post-test.

\section{The Analysis of Students' Response to Collaborative Strategic Reading (CSR)}

\begin{tabular}{|c|l|c|c|c|c|c|}
\hline No. & Questions & $\begin{array}{c}\text { Strongly } \\
\text { Agree }\end{array}$ & Agree & Neutral & Disagree & $\begin{array}{c}\text { Strongly } \\
\text { Disagre }\end{array}$ \\
\hline 1 & $\begin{array}{l}\text { I like to learn English in the } \\
\text { classroom through Collaborative } \\
\text { Strategic Reading (CSR) strategy. }\end{array}$ & $50 \%$ & $45 \%$ & $5 \%$ & $0 \%$ & $0 \%$ \\
\hline 2 & $\begin{array}{l}\text { I enjoy learning English in the } \\
\text { classroom through Collaborative } \\
\text { Strategic Reading (CSR) strategy. }\end{array}$ & $70 \%$ & $20 \%$ & $5 \%$ & $5 \%$ & $0 \%$ \\
\hline 3 & $\begin{array}{l}\text { The reading class is more } \\
\text { interesting when Collaborative } \\
\text { Strategic Reading (CSR) is } \\
\text { implemented in the classroom. }\end{array}$ & $60 \%$ & $40 \%$ & $0 \%$ & $0 \%$ & $0 \%$ \\
\hline 4 & $\begin{array}{l}\text { After attending the Collaborative } \\
\text { Strategic Reading (CSR) } \\
\text { classroom, I can take benefits, } \\
\text { such as improving motivation, self } \\
\text { esteem, and achievement. }\end{array}$ & $50 \%$ & $35 \%$ & $15 \%$ & $0 \%$ & $0 \%$ \\
\hline 5 & $\begin{array}{l}\text { By attending the Collaborative } \\
\text { Strategic Reading (CSR) } \\
\text { classroom, I can share ideas to the } \\
\text { members of the group. }\end{array}$ & $80 \%$ & $10 \%$ & $10 \%$ & $0 \%$ & $0 \%$ \\
\hline 6 & $\begin{array}{l}\text { During the learning activity in the } \\
\text { Collaborative Strategic Reading } \\
\text { (CSR) classroom, always } \\
\text { participate actively within a group. }\end{array}$ & $40 \%$ & $45 \%$ & $15 \%$ & $0 \%$ & $0 \%$ \\
\hline 7 & $\begin{array}{l}\text { During the learning activity in the } \\
\text { Collaborative Strategic Reading } \\
\text { (CSR) classroom, I always help }\end{array}$ & $50 \%$ & $50 \%$ & $0 \%$ & $0 \%$ & $0 \%$ \\
\hline
\end{tabular}




\begin{tabular}{|c|l|l|l|l|l|l|}
\hline & $\begin{array}{l}\text { each other with my friends within } \\
\text { a group. }\end{array}$ & & & & & \\
\hline 8 & $\begin{array}{l}\text { During the learning activity in the } \\
\text { Collaborative Strategic Reading } \\
\text { (CSR) classroom, I always } \\
\text { appreciate my friends opinion. }\end{array}$ & $35 \%$ & $55 \%$ & $10 \%$ & $0 \%$ & $0 \%$ \\
\hline 9 & $\begin{array}{l}\text { During the learning activity in the } \\
\text { Collaborative Strategic Reading } \\
\text { (CSR) classroom, I always pay } \\
\text { attention when my friends are } \\
\text { sharing ideas within a group. }\end{array}$ & $55 \%$ & $25 \%$ & $20 \%$ & $0 \%$ & $0 \%$ \\
\hline 10 & $\begin{array}{l}\text { During the learning activity in the } \\
\text { Collaborative Strategic Reading } \\
\text { (CSR) classroom, I can work } \\
\text { cooperatively with my friends } \\
\text { within a group. }\end{array}$ & $65 \%$ & $30 \%$ & $5 \%$ & $0 \%$ & $0 \%$ \\
\hline
\end{tabular}

Chart of Analysis of Students' Response to Collaborative Strategic Reading

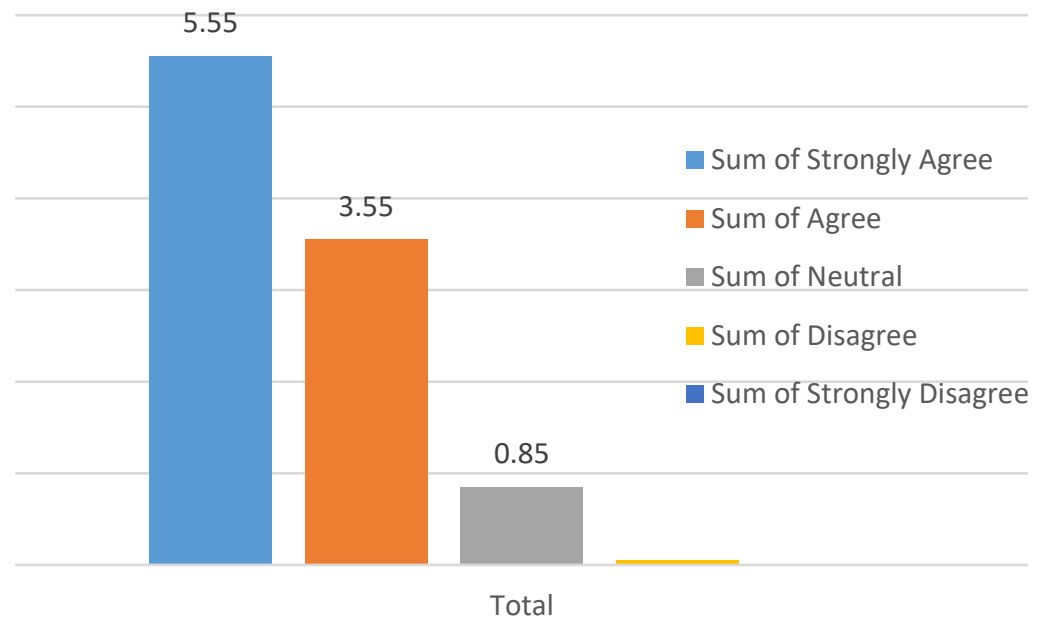

\section{CONCLUSION AND SUGGESTIONS}

Analysis of the results of pre-test for the experimental and control groups indicate on average 66.6 students of experimental group are able to answer about $67 \%$ of the whole pre-test items. Meanwhile, the result of pre-test of the control group shows that on average 64 students of control group are able to answer about $64 \%$ of the whole pretest items. The calculation of the scores of the posttest suggest that the students of the experimental group are able to answer about $74 \%$ of the whole post-test items, compared to the mean score of the pre-test (i.e., 67\%). The difference between the two scores indicates that there is a significant increase in the students' achievement in reading comprehension.

In other case, the analysis of the students' scores using the t-test provides further evidence that the score of the $t_{\text {value }}$ is higher than $t_{\text {table }}(2.18>2.021)$. This means that there is a significant improvement in the students' achievement after they got treated using Collaborative Strategic Reading (CSR) strategy when studying reading 
comprehension in the classroom. Thus, it can be concluded that Collaborative Strategic Reading (CSR) strategy contributes very much to the increase of the students' achievement in the teaching and learning processes for reading comprehension at Universitas Pendidikan Muhammadiyah Sorong.

In addition to applying the previous analysis approaches, this research also analyses the students' responses to Collaborative Strategic Reading (CSR). In this case, the researcher has constructed a questionnaire that consists of ten questions in order to identify students' positive or negative response to the new strategy. The results of the analysis of the students' response to the application of Collaborative Strategic Reading (CSR) strategy in the teaching learning activities in the classroom provide a strong preference for the students study reading comprehension using Collaborative Strategic Reading (CSR) strategy. This can be seen from the finding that most of the students indicate their 'strong agreement' towards the usefulness and effectiveness of the use of CSR strategy for teaching them reading comprehension in the classroom. This means that the students found Collaborative Strategic Reading (CSR) as an effective strategy for studying reading comprehension which is intended to increase their reading achievement.

\section{BIBLIOGRAPHY}

Abidin, Mohamad J. Z. 2012. "Collaborative Strategic Reading (CSR) within Cognitive and Metacognitive Strategies perspectives." International Journal of Humanities and Social Science, 02, 192-198.

Blachowicz, C., and Ogle, D. 2008. Reading Comprehension: Strategies for Independet Learners. New York: The Guilford Press.

Blass, Laurie. 2007. Skills and Strategies for Reading. Oxford: Oxford University Press.

Anderson, H., Hourcade, J. \& Parette, P. (2003). Accountability in Collaboration: A Framework for Evaluation. Education and Training in Developmental Disabilities, 38(4), 398-404.

Austin, A. L. (2001). Teachers' Beliefs About Co-Teaching. Remedial and Special Education, 22(4), 245-255.

Fan, Y.C. 2010. Implementing Collaborative Strategic Reading (CSR) in an EFL context in Taiwan. Unpublished Thesis. Available at http://Ira.le.ac.uk/handle/2381/434. Retrieved on June $17^{\text {th }} 2015$.

Fitri, A. 2010. The effectiveness of Collaborative Strategic Reading (CSR) on the Reading Comprehension Achievement of the Fourth Semester Students of PGSD Suryalaya, West Java, Indonesia. Unpublished Thesis. Post Graduate Program of UM. Available at http://karyaiImiah.um.ac.id/index.php/disertasi/article/view/8238/0. Retrieved on June $17^{\text {th }} 2015$.

Keef, E.B. \& Moore, V. (2004). The Challenge of Co-Teaching in the Inclusive Classrooms at eh High School Level: What the Teacher Told Us. American Secondary Education, 32(3)77-88.

Klingner, J.K., Vaughn, S. Boardman A., and Swanson, E. (2012). Now we get it!: boosting comprehension with collaborative strategic reading. USA: John Wiley \& Sons. 
Klingner, J.K., Vaughn, S., Dimino, J., Schumm, J., S., \& By\ryant, D. (2002). Collaborative stragetic reading. Colorado: Sopris West.

Lezotte, L.W. (2004) Learning for All. Okemos, MI. Effective Schools Products, Ltd. Dettmer, P., Thurston, L.P., \& Dyck, N. (2002). Consultation, Collaboration, and Teamwork for Students with Special Needs, Fouth Edition. Boston, MA. Allyn and Bacon.

Loader, L.M. (1993). A Collaborative Approach to Mainstreaming. The Delta Kappa Gamma Bulletin, Fall 1993, 34-38.

Mastropieri, M. A., Scruggs, T. E., Graetz, J., Norland, J., Gardizi, W., McDuffie, K., et al. (2005). Case Studies in Co-Teaching in the Content Areas: Successes, Failures, and Challenges. Interventions in School and Clinic, 40, 260-270.

Murawski, W.W., \& Swanson, H.L. (2001). A Meta-Analysis of Co-Teaching Research: Where are the Data? Remedial and Special Education, 22(5), 258-267.

Nagurka, T. F. (1995). COILS: The Co-Taught Integrated Learning System Program. (Report no. ED 381-955). New Orleans, LA.: National Conference of the American Association of Administrators.

Spears, Deanne. 2012. Improving Reading Skills: Contemporary Readings for College Students $\left(7^{\text {th }}\right.$ ed.). New York: McGraw-Hill Companies, Inc.

Spencer, S.A. (2005). Lynne Cook and June Downing: The Practicalities of Collaboration in Special Education Service Delivery. Intervention in School \& Clinic, 40(5), 296-300.

Villa, R., Thousand, S., \& Nevin, A. (2004). A Guide to Co-Teaching: Practical Tips for Facilitating Student Learning. Thousand Oaks, CA. Corwin Press.

Walther-Thomas, C.S. (1997). Co-Teaching Experiences: The Benefits and Problems that Teachers and Principals Report Over Time. Journal of Learning Disabilities. 30(4), 395-407.

Weiss, M. P. \& Lloyd, J. (2003). Conditions for Co-teaching: Lessons from a Case Study. Teacher Education and Special Education, 26(1), 27-41.

Weiss, M. P. \& Lloyd, J. (2002). Congruence Between Roles and Actions of Secondary Special Educators in Co-Taught and Special Education Settings. The Journal of Special Education, 362(2), 58-68.

What Matters Most: Teaching for America's Future (1996). Report of the National Commission on Teaching and America's Future

Wooley, Gary. 2011. Reading Comprehension: Assisting Children with Learning. London: Springer 